Proc. Estonian Acad. Sci. Geol., 1999, 48, 3, 170-186

\title{
SPREAD OF ALNUS AND PICEA IN ESTONIA
}

\author{
Leili SAARSE ${ }^{\mathrm{a}}$, Anneli POSKA ${ }^{\mathrm{a}, \mathrm{b}}$, and Siim VESKI ${ }^{\mathrm{a}}$
}

${ }^{a}$ Institute of Geology, Tallinn Technical University, Estonia pst. 7, 10143 Tallinn, Estonia; saarse@gi.ee, veski@gi.ee

${ }^{b}$ Institute of Earth Sciences/Quaternary Geology, Uppsala University, Villavägen 16, S-75236 Uppsala, Sweden; anneli.poska@natgeog.uu.se

Received 1 March 1999

Abstract. The spread of alder (Alnus glutinosa and A. incana) and spruce (Picea abies (L.) Karst.) in Estonia is reviewed on the basis of 43 radiocarbon dated pollen diagrams and 10 macrofossil records from lake and bog profiles. Alder immigrated 9200-7700 BP, expanded 9100-6800 BP, and reached its maximum values 8400-3600 BP. Timing of alder spread varies considerably with sites and regions. The first stands of spruce dating to 8000-7500 BP were recorded in southeastern Estonia. Spruce reached the northern coastal area at the end of the Atlantic with an average range rate of about $100 \mathrm{~m} \mathrm{yr}^{-1}$. The first spruce maximum is intermittent between 4000 and $2800 \mathrm{BP}$; the second maximum, not expressed in all examined pollen diagrams, is commonly between 2000 and 1000 BP. The macroremains of Picea evidence that spruce grew locally 1000-2000 years earlier than revealed in pollen record.

Key words: Alnus, Picea, pollen, stratigraphy, Holocene, Estonia.

\section{INTRODUCTION}

Several local and regional Holocene pollen-stratigraphic studies record the spatial and temporal pattern of the immigration of different taxa to Estonia and their expansion (Ilves \& Mäemets, 1987; Pirrus et al., 1987b; Saarse \& Königsson, 1992; Königsson \& Poska, 1998; Königsson et al., 1998; Veski, 1998). This has encouraged the authors to give an overview of the spread of alder and spruce in Estonia. The immigration and expansion of Alnus and Picea are of interest from the stratigraphic aspect, as both taxa have been used in the Estonian Holocene stratigraphic chart (Raukas et al., 1995). The Pinus-Alnus pollen assemblage zone (PAZ) corresponds to the Late Boreal, the Betula-Alnus PAZ to the Early Sub-Atlantic, the Picea PAZ to the Late Sub-Boreal, and the BetulaPinus-Picea PAZ to the Middle Sub-Atlantic.

It has been assumed that Alnus glutinosa was the main alder species in Estonia by the presence of Alnus incana (Thomson, 1939). Spruce was 
represented by Picea abies (L.) Karst., or Norway spruce, which today dominates large areas of Boreal forest in Fennoscandia and northern Russia (Huntley, 1988).

The spread of alder in Estonia has not been treated earlier. Isopoll maps (Huntley \& Birks, 1983) refer the presence of alder in the western and eastern regions of Estonia to the Early Boreal. Less established it was on the uplands (Pandivere and Sakala) and heights (Otepää and Haanja). From 7500 BP onwards alder groves were frequent all over the country, being more abundant at $6500 \mathrm{BP}$ in eastern Estonia (Huntley \& Birks, 1983).

Ilves \& Sarv (1975) completed the first investigation on spruce expansion on the basis of nine well-dated sites (sites $3,11,13,15,20,24,29,36,38$ in Fig. 1)

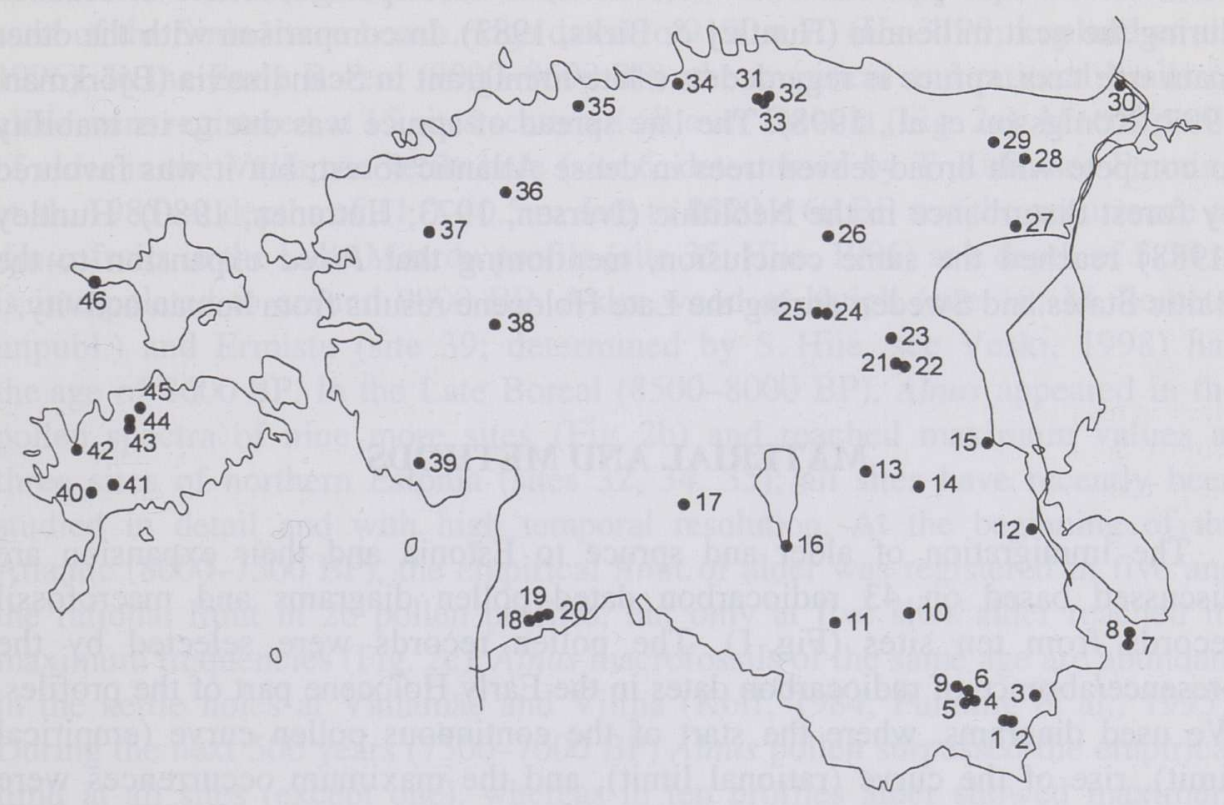

Fig. 1. Location of the examined biostratigraphical sites. 1, Kirikumäe (Saarse \& Rajamäe, 1997); 2, Punso (Saarse \& Rajamäe, 1997); 3, Remmeski (Sarv, 1983); 4, Vaskna (Ilves \& Mäemets, 1987); 5, Tuuljärv (Ilves \& Mäemets, 1987); 6, Vällamäe (Punning et al., 1985, 1995); 7, Senno (Sarv, 1983); 8, Obtjok (Miidel et al., 1995); 9, Palanumäe (M. Ilomets, unpubl.); 10, Kuigli (M. Ilomets, unpubl.); 11, Kuiksilla (Ilves et al., 1967); 12, Kalsa (K. Kimmel, unpubl.); 13, Ulila (Ilves \& Sarv, 1970); 14, Rebase (M. Ilomets, unpubl.); 15, Saviku (Sarv \& Ilves, 1975); 16, Võrtsjärv (Pirrus et al., 1993); 17, Päidre (Saarse et al., 1995); 18, Nigula 1 (Sarv \& Ilves, 1976); 19, Nigula 2 (Sarv \& Ilves, 1976); 20, Mõksi (Sarv \& Ilves, 1976); 21, Raigastvere (Pirrus et al., 1987b); 22, Elistvere (L. Saarse, unpubl.); 23, Laiuse (Pirrus et al., 1987a); 24, Teosaare (Ilves et al., 1968); 25, Linnusaare (L. Saarse, unpubl.); 26, Äntu (Saarse \& Liiva, 1995); 27, Võhma (K. Kimmel, unpubl.); 28, Liivjärv (Koff, 1994); 29, Kalina (Ilves \& Sarv, 1969); 30, Leekovo, Sininõmme (Lepland et al., 1996); 31, Viitna kettle hole (Koff, 1984); 32, Viitna Linajärv (R. Pirrus, unpubl.); 33, Viitna Pikkjärv (Saarse et al., 1998); 34, Kahala (Poska \& Saarse, 1999); 35, Maardu (Veski, 1998); 36, Vaharu (Sarv \& Ilves, 1971); 37, Mustjärv (Veski, 1998); 38, Velise (Veski, 1998); 39, Ermistu (Veski, 1998); 40, Järvesoo (Saarse, 1994); 41, Pitkasoo (Königsson \& Poska, 1998); 42, Vedruka (A. Poska, unpubl.); 43, Pelisoo (Saarse \& Königsson, 1992); 44, Jõhvikasoo (Hansson et al., 1996); 45, Surusoo (Veski, 1998); 46, Kõivasoo (Königsson et al., 1998). 
already 25 years ago. Unlike Thomson (1929), who mentioned the eastern route in spruce immigration, they suggested a southeasterly direction, as the eastern route was blocked by large Lake Peipsi. Ilves \& Sarv (1975) also noted that spruce maximum dispersal occurred at different times, explaining it by the local climatic conditions. According to pollen-stratigraphical studies (Thomson, 1927, 1929; Sarv, 1983; Ilves \& Mäemets, 1987; Pirrus et al., 1993; Saarse \& Rajamäe, 1997) and isopoll maps (Huntley \& Birks, 1983), spruce was present in southeastern Estonia and the surrounding areas already at the end of the Late Glacial, but disappeared during the Pre-Boreal and Boreal. Spruce reappeared at about $7000 \mathrm{BP}$, and at $6000 \mathrm{BP}$ it spread over most of the mainland, except the northwesternmost part and the West Estonian Archipelago, where it reached during the next millennia (Huntley \& Birks, 1983). In comparison with the other main tree taxa, spruce is regarded as a late immigrant in Scandinavia (Björkman, 1997; Königsson et al., 1998). The late spread of spruce was due to its inability to compete with broad-leaved trees in dense Atlantic forest, but it was favoured by forest disturbance in the Neolithic (Iversen, 1973; Huttunen, 1980). Huntley (1988) reached the same conclusion, mentioning that Picea expansion to the Baltic States and Sweden during the Late Holocene results from human activity.

\section{MATERIAL AND METHODS}

The immigration of alder and spruce to Estonia and their expansion are discussed based on 43 radiocarbon dated pollen diagrams and macrofossil records from ten sites (Fig. 1). The pollen records were selected by the presence/absence of radiocarbon dates in the Early Holocene part of the profiles. We used diagrams, where the start of the continuous pollen curve (empirical limit), rise of the curve (rational limit), and the maximum occurrences were dated, or at least there were radiocarbon dates below and above the mentioned events. If the empirical and rational limits and maximum occurrence of spruce and alder were not dated, radiocarbon dates below and above these limits were extrapolated, as was done by Bennett \& Birks (1990) in analysing the alder distribution in the British Isles. All radiocarbon dates quoted in the text are uncalibrated radiocarbon years before present (BP). Pollen sum at sites 21,34 , $35,37,38,39,41,42,44,45$ was around 1000 arboreal pollen (AP) counts, sites 4 and 5 yielded even more and all other profiles about 250-300 AP grains per level. The spruce pollen is probably underrepresented in the case of low pollen sum (less than 300).

The isochrone maps of spruce were constructed using the well-known method of Birks (1989). The grid-based approach was not applied, as it is rather timeconsuming and produces results consistent with the first-mentioned method (King \& Herstrom, 1997). 


\section{RESULTS}

Alder distribution. The timing of empirical and rational limits and maximum occurrence of alder is displayed in Fig. 2a-d at 500-year intervals and in Fig. 3. At three sites - Viitna Linajärv (site 32; R. Pirrus, unpubl.), Viitna Pikkjärv (site 33; Saarse et al., 1998), and Mustjärv (site 37; Veski, 1998) - alder was present in pollen records at the end of the Pre-Boreal, confirming so Thomson's (1927) assumption that Ulmus, Corylus, and Alnus reached Estonia at the end of the PreBoreal. Pieces of alder wood have been found in a depression between the Sininõmme beach ridge superimposed by an aeolian formation (site 30 ) and klint near Narva and dated to $9700 \pm 75$ (Ua-3193), and in the upper part of offshore sand of the Sininõmme beach ridge dated to $9190 \pm 70$ (Ua-3190; Lepland et al., 1996). In the Early Boreal (9000-8500 BP), the empirical and rational limits of alder were registered at 15 sites scattered all over Estonia (Fig. 2a). Macrofossils of alder in the Vällamäe kettle hole (site 6; determined by T. Koff, see Punning et al., 1985) at depths of 11.0-10.5 m date to $8820 \pm 60 \mathrm{BP}$ and the occurrence of Alnus fruits in the Lake Maardu profile (site 35; Hiie, 1996) at a depth of $5.30 \mathrm{~m}$ is interpolated to around 9000 BP. Alder wood at Kuigli (site 10; M. Ilomets, unpubl.) and Ermistu (site 39; determined by S. Hiie, see Veski, 1998) has the age of $8600 \mathrm{BP}$. In the Late Boreal (8500-8000 BP), Alnus appeared in the pollen spectra of nine more sites (Fig. $2 \mathrm{~b}$ ) and reached maximum values at three sites of northern Estonia (sites 32, 34, 35); all sites have recently been studied in detail and with high temporal resolution. At the beginning of the Atlantic (8000-7500 BP), the empirical limit of alder was registered in five and the rational limit in 26 pollen profiles, but only at five sites alder reached its maximum frequencies (Fig. 2c). Alnus macrofossils of the same age are abundant in the kettle holes at Vällamäe and Viitna (Koff, 1984; Punning et al., 1995). During the next 500 years (7500-7000 BP) Alnus pollen surpassed the empirical limit at all sites (except one), whereas in ten profiles alder showed maximum values (Fig. 2d). Alder macrofossils are richly present in the Vällamäe kettle hole (Punning et al., 1985, 1995). By $6500 \mathrm{BP}$ alder had reached its maximum in 21 pollen profiles. Besides the above-mentioned sites, its macroremains have also been identified at Palanumäe (site 9; M. Ilomets, unpubl.) and Jõhvikasoo (site 44; Hansson et al., 1996). In the Late Atlantic (6500-5000 BP), alder maximum frequencies were identified at nine sites, dispersed in different regions. The latest alder maximum was registered in the southeastern profiles (sites 2, 4, $5,7,12$ ). Timing of the spread and increase of alder is portrayed in Fig. 3, suggesting that alder quickly reached its rational limit everywhere, whereas its maximum occurrence is dispersed between 8400 and 3600 BP. Unfortunately, due to the patchy character of alder distribution, compilation of isochrone maps for this taxon proved impossible.

Spruce distribution. The main problems arising in the interpretation of spruce pollen analytical results is the so-called tail in the pollen diagrams, e.g. 


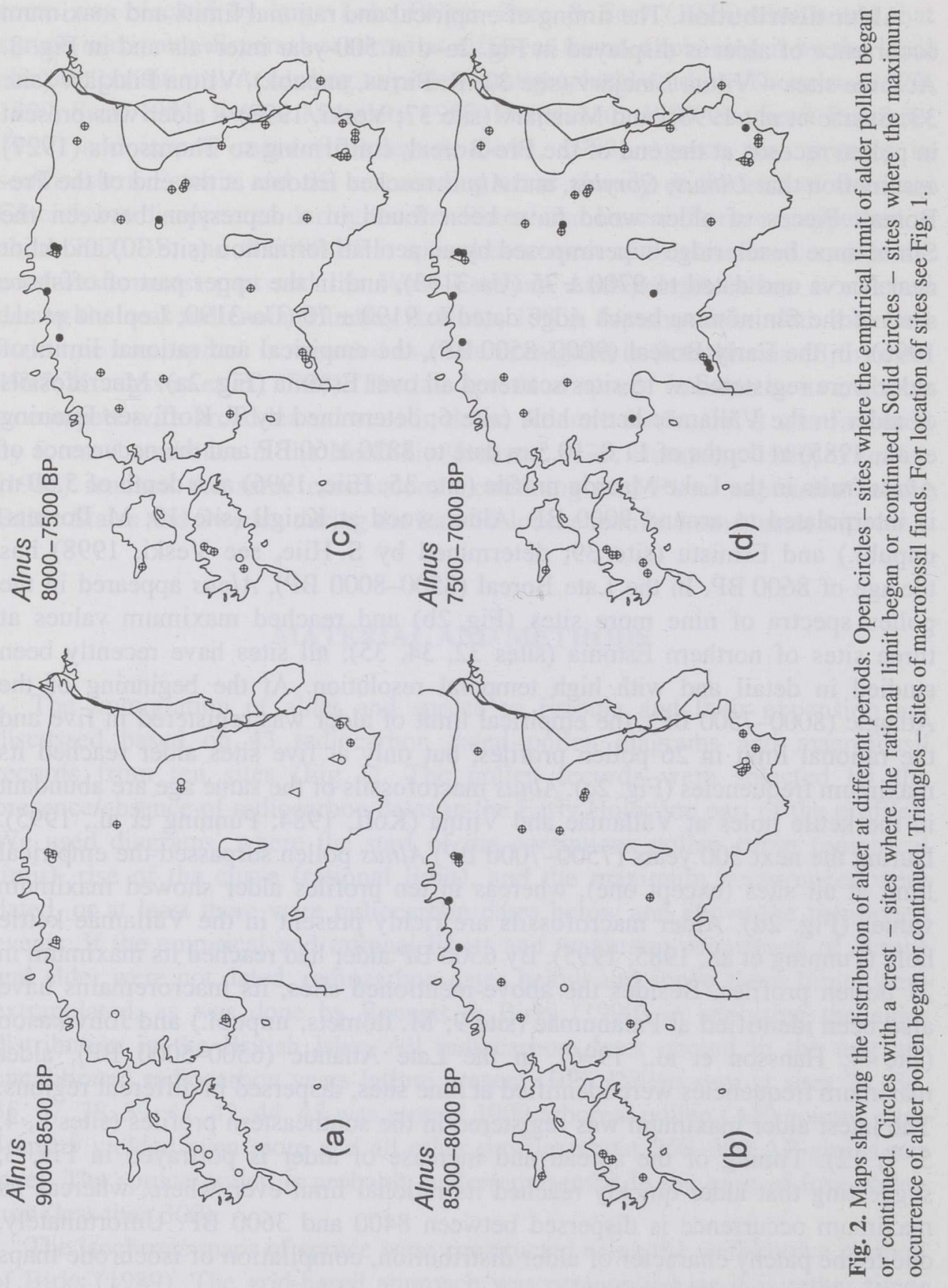


low pollen percentages before the main rise of the pollen curve. Was this part of pollen deposited mainly in situ, redeposited from older sediments, or transported by air from long distances? Moe (1970) stated that the Picea pollen values of 5-10\% denote either the presence of a considerable number of spruce trees in the area proper or up to 50 km away, but the Picea values of $1-3 \%$ are due to long-distance transport. In the present study the arrival of spruce at the site was defined by a pollen threshold value of $2-3 \%$ which was exceeded in three consecutive samples. However, this does not conform with the latest simulation results, which show that pollen loading of spruce increased steeply when the spruce front reached the area and pollen curves formed a plateau as the spruce front moved a few kilometres away from the investigated site (Davis \& Sugita, 1997).

Spruce pollen is strongly underrepresented in modern pollen rain. Hicks's (1977, 1994, 1996) investigations of modern pollen rain in northern Finland show that on the northern limit of spruce-dominated forest the share of the Picea pollen rarely exceeds $5-10 \%$ and outside the forest Picea pollen values diminish sharply $(<1 \%)$. Modern pollen rain monitoring in southeastern Estonia gives evidence of a similar pattern. In spruce-dominated forest the Picea pollen values range from $10 \%$ to $20 \%$, dropping abruptly outside the forest $(<5 \%)$. In the light of this data, the percentage $2-3$ of spruce pollen seems to be sufficient to indicate its establishment.

Spruce pollen, with the values above $10 \%$, has been identified in the profiles of southeastern Estonia already during the Younger Dryas, which suggests the presence of spruce (Thomson, 1929; Sarv \& Ilves, 1975; Huntley \& Birks, 1983; Saarse \& Rajamäe, 1997). In the pollen proxy record from lakes Tuuljärv (site 5) and Vaskna (site 4), which was analysed in detail, spruce pollen was continuously present from the Younger Dryas onwards, however, in low amounts (Ilves \& Mäemets, 1987). As macroremains of spruce dated to the Younger 

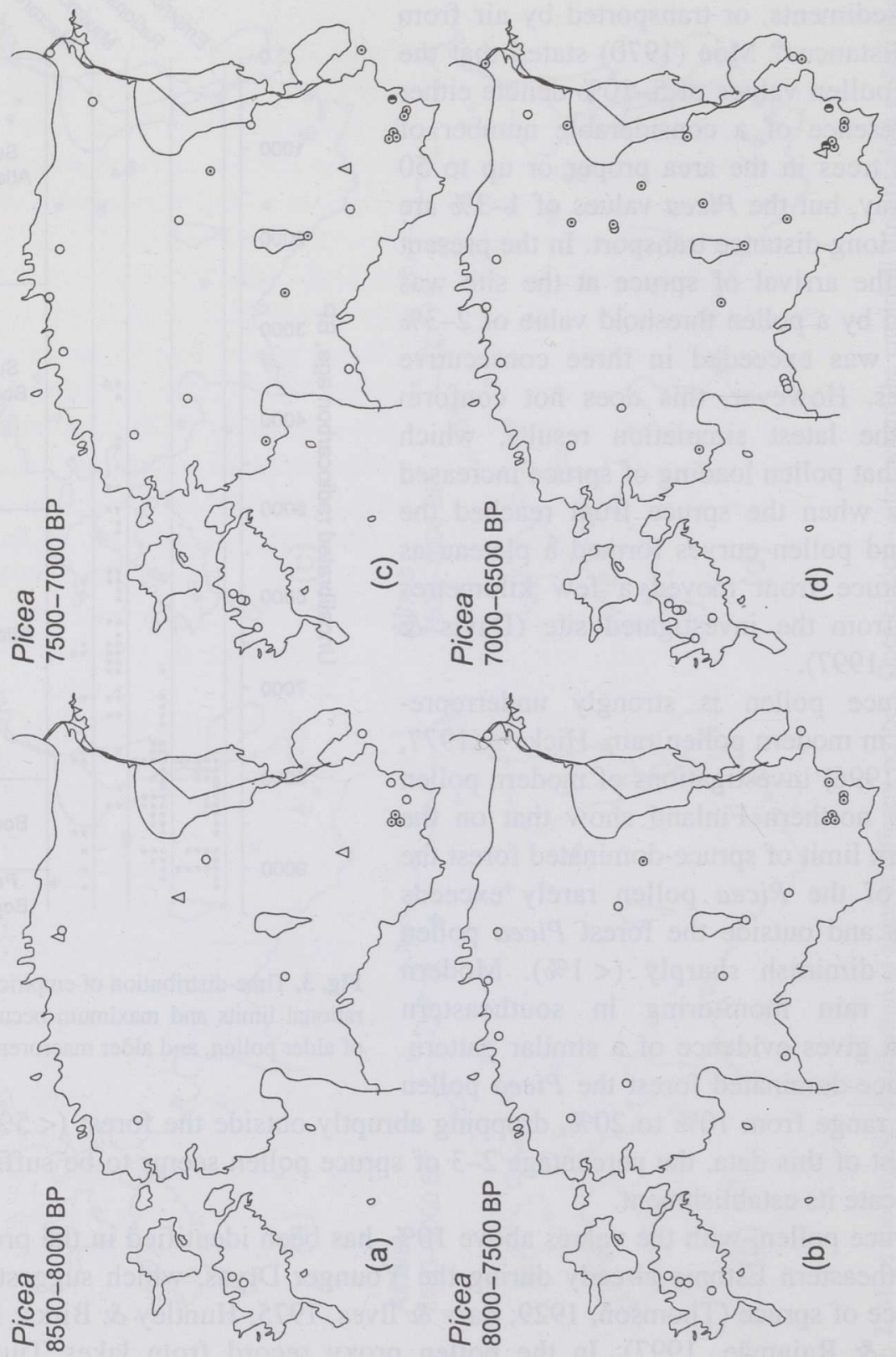


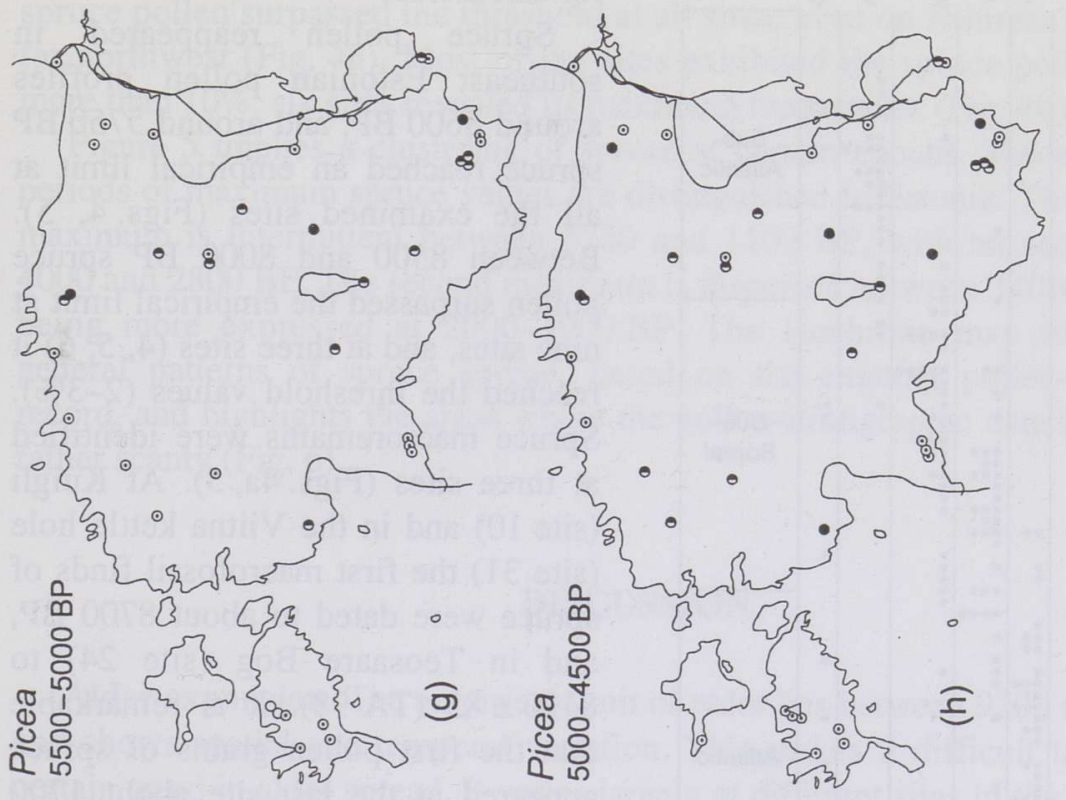

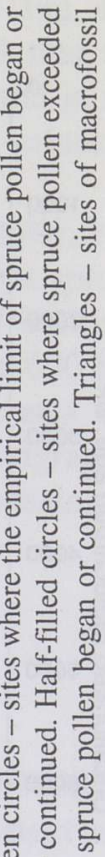

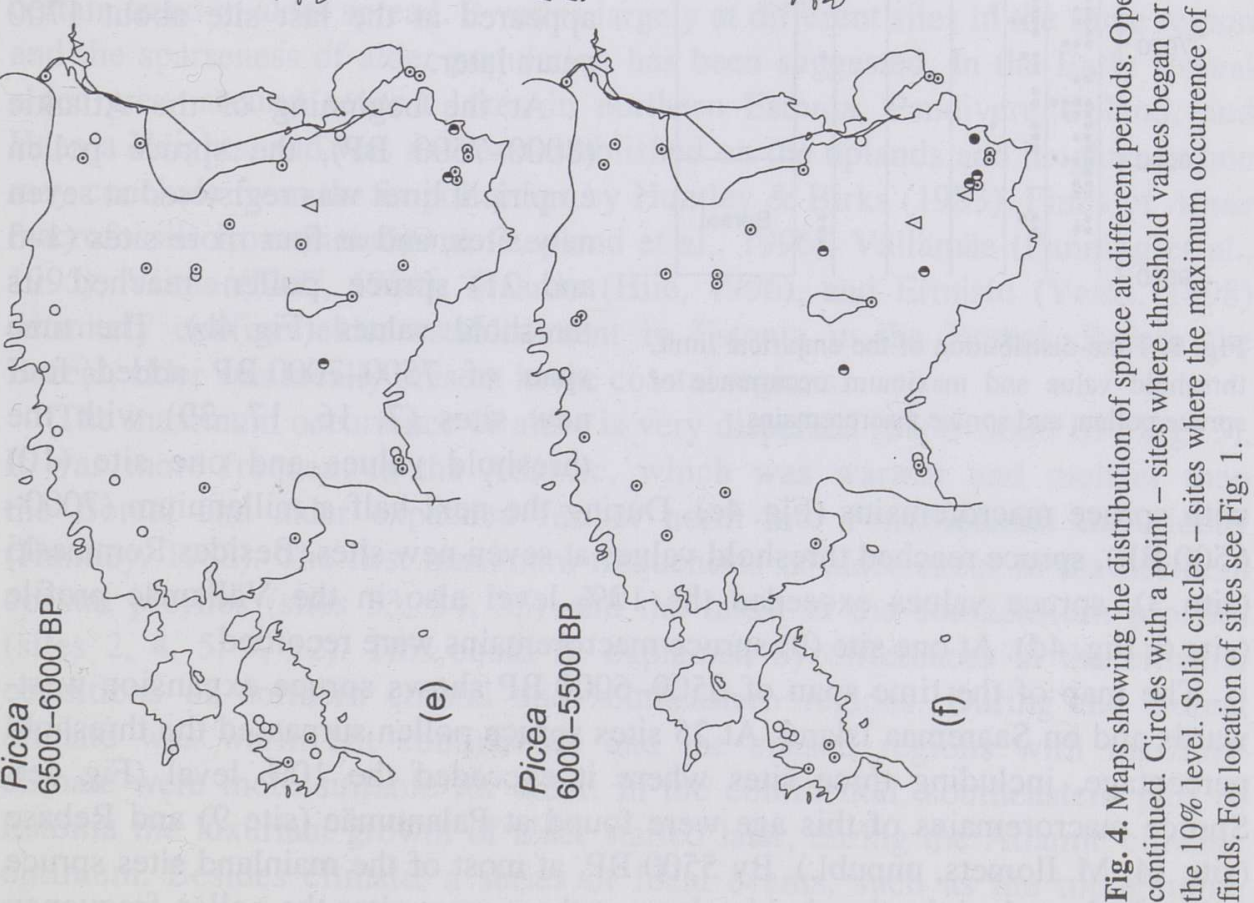




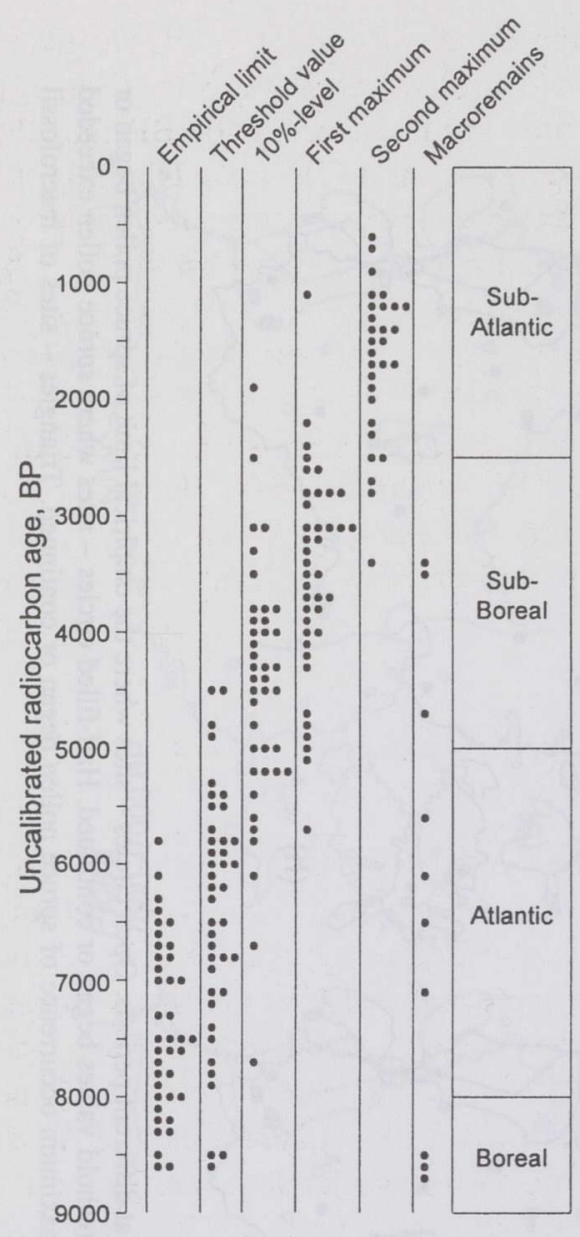

Fig. 5. Time-distribution of the empirical limit, threshold value and maximum occurrence of spruce pollen, and spruce macroremains.

Dryas or Pre-Boreal have not been found, the question of its Pre-Holocene immigration to Estonia is still open for discussion.

Spruce pollen reappeared in southeast Estonian pollen profiles around $8600 \mathrm{BP}$, and around $5750 \mathrm{BP}$ spruce reached an empirical limit at all the examined sites (Figs. 4, 5). Between 8500 and 8000 BP spruce pollen surpassed the empirical limit at nine sites, and at three sites $(4,5,6)$ it reached the threshold values $(2-3 \%)$. Spruce macroremains were identified at three sites (Figs. 4a, 5). At Kuigli (site 10) and in the Viitna kettle hole (site 31 ) the first macrofossil finds of spruce were dated to about $8700 \mathrm{BP}$, and in Teosaare Bog (site 24) to $8490 \pm 85$ (TA-98). It is remarkable that the first pollen grains of spruce appeared at the last site about 1700 years later.

At the beginning of the Atlantic (8000-7500 BP), the spruce pollen empirical limit was registered at seven new sites, and at four more sites (1-3 and 21) spruce pollen reached its threshold values (Fig. 4b). The time span of 7500-7000 BP added four new sites $(7,16,17,39)$ with the threshold values and one site (10) with spruce macroremains (Fig. 4c). During the next half a millennium (7000 $6500 \mathrm{BP})$, spruce reached threshold values at seven new sites. Besides Remmeski (site 3 ), spruce values exceeded the $10 \%$ level also in the Vällamäe profile (site 6, Fig. 4d). At one site (9) spruce macroremains were recorded.

The map of the time span of $6500-6000$ BP shows spruce expansion westwards and on Saaremaa Island. At 25 sites spruce pollen surpassed the threshold percentage, including three sites where it exceeded the $10 \%$ level (Fig. 4e). Spruce macroremains of this age were found at Palanumäe (site 9) and Rebase (site 14; M. Ilomets, unpubl.). By $5500 \mathrm{BP}$, at most of the mainland sites spruce pollen had reached the threshold values, at three more sites the pollen frequency exceeded $10 \%$, and one site displayed its maximum occurrence (Fig. 4f). By 
the end of the Atlantic, spruce reached the threshold values in all mainland profiles except one (site 12) and maximum values at three sites (Fig. 4g). However, it was not until the end of the time span of 5000-4500 BP that the spruce pollen surpassed the threshold at all sites, even on Hiiumaa Island in the far northwest (Fig. 4h). Most of the sites exhibited the spruce pollen values of more than 10\%; six sites revealed its maximum frequencies (Fig. 4h).

Figure 5 implies a clustering of spruce at certain epochs. Traditionally, two periods of maximum spruce values are distinguished in Estonia. The first spruce maximum is intermittent between 5750 and $1100 \mathrm{BP}$, with an accent between 4000 and $2800 \mathrm{BP}$. The second maximum is dispersed between 3400 and $600 \mathrm{BP}$, being more expressed at $2000-1000 \mathrm{BP}$. The isochrone map illustrates the general patterns of spruce spread, based on the existing pollen-stratigraphic record, and highlights the areas where the pollen-stratigraphic data is missing or rather scanty (Fig. 6).

\section{DISCUSSION}

Alder expansion. The empirical limit of alder lies between 9200 and 7600 BP and shows spatial and temporal variation. This makes it difficult to detect any certain trend in alder spread. It varies largely at different sites in the same region and the sparseness of alder population has been suggested. In the Early Boreal alder grew around several lakes in northern Estonia, Pandivere Upland, and Haanja Heights, and was not less established on the uplands and heights, as one may conclude from the isopoll maps by Huntley \& Birks (1983). Finds of Alnus macrofossils from Sininõmme (Lepland et al., 1996), Vällamäe (Punning et al., 1995), Viitna (Koff, 1984), Maardu (Hiie, 1996), and Ermistu (Veski, 1998) definitely confirm alder establishment in Estonia in the Boreal. Before the Boreal, alder was locally present in the coastal regions.

The maximum occurrence of alder is very dispersed (8400-3600 BP; Fig. 3). It was more frequent in the Atlantic, which was warmer and moister than the Boreal and alder expanded further north into Fennoscandia than today (Huntley, 1988). The first maximum frequencies of alder occur in the northern coastal profiles (sites $33,34,35$ ) and the latest in the southeastern profiles (sites $2,4,5,7,12$ ). This could be explained by differences in the climatic conditions of northern coastal and southeastern regions. During the Boreal climate was warm but continental, and the coastal regions with maritime climate were more suitable for alder. In the continental, southeastern part of Estonia the luxuriant growth of alder started later, during the Atlantic climatic optimum. Besides climate, a series of local events, such as the topography, hydrology, and factors influencing seedling establishment, determined the distribution of alder (Birks, 1989). The alder forest at Luidja on the Kõpu 
Peninsula, Hiiumaa, could possibly be a modern analogue of the early Holocene coastal alder stands.

On many pollen diagrams the alder curve starts with a sharp rise and soon reaches its maximum values. The reason for that is not quite clear, but one can argue some possibilities. First, when Alnus reached a site, it usually surrounded the wet habitat with a rim and its pollen became dominant very fast. Second, overgrowth of the coastal shallow lakes took place in the Boreal, providing suitable habitats for alder to colonize. Alder had a patchy distribution already primarily due to its edaphic demands (nutrient-rich wet soils) and relatively mild climate (Bennett \& Birks, 1990; Ellenberg, 1991), which makes its spread and establishment highly dependent on the seed dispersal to a new favourable habitat. Reaching a suitable site, the alder is highly competitive and can expand extremely quickly.

Similar to spruce, the alder pollen is almost constantly present in all studied Late Glacial profiles (Pirrus, 1969, 1976; Sarv, 1983; Saarse \& Rajamäe, 1997). Possibly it was redeposited from interglacial sediments.

Spruce expansion. Studying the Younger Dryas mire stratigraphy in the vicinity of Izborsk, Thomson $(1927,1929)$ suggested spruce occurrence in the region already in the Pre-Holocene. In the Remmeski profile covering the Younger Dryas, up to $20 \%$ spruce pollen has been recorded (Sarv, 1983). Recent investigations have implied that in the southeastern profiles with the pollen counts of more than 500-1000, sparse spruce pollen is continuously present from the Younger Dryas onwards (Ilves \& Mäemets, 1987). In the present-day spruce-dominated forest of northern Finland, Picea pollen values rarely exceed 5\% (Hicks, 1996), which confirms the possibility of spruce survival in the extreme southeast of Estonia during the Younger Dryas. Still, the increased share of spruce pollen could also be due to low pollen productivity of the surrounding area and thus the resedimented pollen of Picea could show up better.

At the end of the Younger Dryas and in the Pre-Boreal, spruce occurrences became occasional or ceased completely. The reappearance of spruce in the pollen profiles of the Boreal (Fig. 4a) can probably also be considered occasional. Still, the isochrone map by Serebryannyi (1971) and the isopoll map by Orgla (1983), compiled for the northwestern part of Russia, provide evidence that spruce was present between Petroskoj and St Petersburg about 8700-8500 BP, while zero isopoll passed Estonia roughly on the Pärnu-Narva line.

The new isochrone map of spruce compiled by the authors of the present paper implies spruce spread from $8000 \mathrm{BP}$ from the southeast (Fig. 6). The spruce forest boundary probably reached the Sakala Upland and the Võrtsjärv basin between 7000 and 6500 BP and the Pärnu-Narva line about 6000 BP. By 5000 BP spruce forest was common in mainland Estonia, except the northwestern part. Several sources of error, like the pollen sum, long-distance transport 


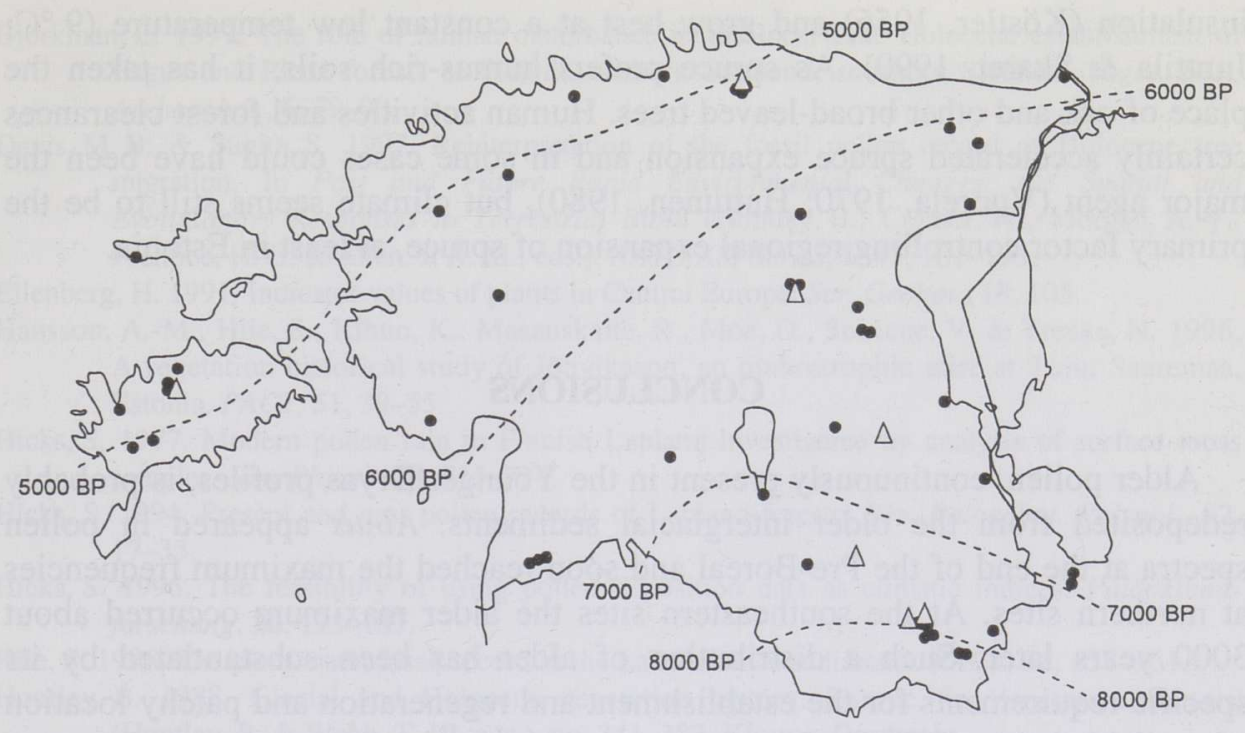

Fig. 6. Isochrone map of spruce expansion. For legend see Fig. 4.

(Tallantire, 1972), the size of the basin (Davis \& Sugita, 1997), affect the validity of the isochrone map. Still, the map shows the general trend in the spread of spruce, which progressively extended its range northwestwards during the Atlantic.

Some confusion has arisen in connection with the macrofossil find of spruce in the Teosaare profile dated to $8495 \pm 85$ (TA-98), which is 1700 years before the regional spread of spruce. In the Viitna kettle hole the first macrofossil remains of spruce are recorded 2700 years earlier than pollen. Tallantire (1972) mentioned the same phenomenon in Fennoscandia, where the macrofossil finds were at least 1000 years older than the regional spread of spruce on the basis of pollen data. The most recent discovery of broad-leaved and spruce macroremains in central Sweden shows that spruce grew there $8000 \mathrm{BP}$, or about 5000 radiocarbon years before the pollen record (Kullman, 1996, 1998). It shows that small scattered spruce populations could have grown locally thousands of years before spruce forest reached the area.

The low-rate range of spruce in Estonia, about $100 \mathrm{~m} \mathrm{yr}^{-1}$, was mostly due to a rather warm climate and a dense forest canopy formed by broad-leaved trees. This explains why spruce was subdued in the Atlantic, with maximum occurrences in the Sub-Boreal (Fig. 5). Then the climate became more continental and caused broad-leaved trees to cease, and favourable habitats were established for spruce. Spruce prefers a relatively continental climate, plentiful snow cover to protect seedlings, and a smoothly rising spring temperature without sharp fluctuations (Tallantire, 1972). The seedlings are also sensitive to drought, overheating, direct 
insulation (Köstler, 1956) and grow best at a constant low temperature $\left(9{ }^{\circ} \mathrm{C}\right.$; Junttila \& Skaret, 1990). As spruce prefers humus-rich soils, it has taken the place of oak and other broad-leaved trees. Human activities and forest clearances certainly accelerated spruce expansion and in some cases could have been the major agent (Vuorela, 1970; Huttunen, 1980), but climate seems still to be the primary factor controlling regional expansion of spruce, at least in Estonia.

\section{CONCLUSIONS}

Alder pollen, continuously present in the Younger Dryas profiles, is probably redeposited from the older interglacial sediments. Alnus appeared in pollen spectra at the end of the Pre-Boreal and soon reached the maximum frequencies at northern sites. At the southeastern sites the alder maximum occurred about 3000 years later. Such a distribution of alder has been substantiated by its specific requirements for the establishment and regeneration and patchy location of available habitats.

The uneven and patchy spread of alder is in contrast with the time-transgressive spread of spruce in Estonia. The quite obvious southeast-northwest immigration direction of spruce has been confirmed. During the Younger Dryas and in the Boreal, spruce was established only in the extreme southeast and its population was sparse. Local small spruce stands occurred 1000-2000 years before the spruce forest front reached the area, being in some places delayed due to unfavourable ecological or soil conditions.

Comparison of the immigration and expansion of alder and spruce manifests the different response of these species to climate with Alnus being most broadly distributed at 7500-5500 BP, and Picea at 5000-3000 BP. Contrary to spruce, Alnus became abundant first in the northern coastal areas with maritime climate and later in more continental southeastern Estonia.

\section{ACKNOWLEDGEMENTS}

The authors are grateful to A. Raukas and A. Miidel for critical reading of the manuscript and colleagues for providing unpublished data. The research was supported by grant No. 3621 of the Estonian Science Foundation.

\section{REFERENCES}

Bennett, K. D. \& Birks, H. J. B. 1990. Postglacial history of alder (Alnus glutinosa (L.) Gaertn.) in the British Isles. J. Quat. Sci., 5, 2, 123-133.

Birks, H. J. B. 1989. Holocene isochrone maps and patterns of tree-spreading in the British Isles. J. Biogeogr., 16, 503-540. 
Björkman, L. 1997. The role of human disturbance in the local Late Holocene establishment of Fagus and Picea forests at Flahult, western Småland, southern Sweden. Veget. Hist. Archaeobot., 6, 79-90.

Davis, M. B. \& Sugita, S. 1997. Reinterpretation of the fossil pollen record of Holocene tree migration. In Past and Future Rapid Environmental Changes: the Spatial and Evolutionary Responses to Terrestrial Biota (Huntley, B., Cramer, W., Morgan, A. V., Prentice, H. C. \& Allen, J. R. M., eds.). NATO ASI Series, 1, 47, 181-193.

Ellenberg, H. 1991. Indicator values of plants in Central Europe. Scr. Geobot., 18, 105.

Hansson, A.-M., Hiie, S., Kihno, K., Masauskaite, R., Moe, D., Seiriene, V. \& Torske, N. 1996. A vegetation historical study of Jõhvikasoo, an ombrotrophic mire at Tuiu, Saaremaa, Estonia. PACT, 51, 39-55.

Hicks, S. 1977. Modern pollen rain in Finnish Lapland investigated by analysis of surface moss samples. New Phytol., 78, 715-734.

Hicks, S. 1994. Present and past pollen records of Lapland forests. Rev. Palaeobot. Palynol., 82, $17-35$.

Hicks, S. 1996. The feasibility of using pollen deposition data as climatic indices. Paläoklimaforschung, 20, 173-187.

Hiie, S. 1996. The plant macrofossil record in the Lake Maardu sediments. PACT, 51, 157-161.

Huntley, B. 1988. Glacial and Holocene vegetation history: Europe. In Vegetation History (Huntley, B. \& Webb, T. III, eds.), pp. 341-383. Kluwer, Dordrecht.

Huntley, B. \& Birks, H. J. B. 1983. An Atlas of Past and Present Pollen Maps for Europe 0-13000 Years Ago. Cambridge University Press, Cambridge.

Huttunen, P. 1980. Early land use, especially the slash-and-burn cultivation in the commune of Lammi, southern Finland, interpreted mainly using pollen and charcoal analyses. Acta Bot. Fenn., 113.

Ilves, E. \& Mäemets, H. 1987. Results of radiocarbon and palynological analyses of coastal deposits of lakes Tuuljärv and Vaskna. In Palaeohydrology of the Temperate Zone III. Mires and Lakes (Raukas, A. \& Saarse, L., eds.), pp. 108-130. Valgus, Tallinn.

Ilves, E. \& Sarv, A. 1969. Die Stratigraphie und Chronologie der organischen Ablagerungen im Hochmoor Kalina. ENSV TA Toim. Keem. Geol., 18, 4, 377-384 (in Russian).

Ilves, E. \& Sarv, A. 1970. Stratigraphie und Chronologie der See- und Torfablagerungen des Moores Ulila (Mittel-Estland). ENSV TA Toim. Keem. Geol., 19, 2, 135-140 (in Russian).

Ilves, E. \& Sarv, A. 1975. Dynamics of the distribution of spruce in Estonia during the postglacial time. In Sostoyanie metodicheskikh issledovanii v oblasti absolyutnoj geokhronologii. Akademiya nauk SSSR, Moskva, 192-197 (in Russian).

Ilves, E., Männil, R. \& Valk, U. 1967. Jääajajärgsete metsade arenemisfaaside vanuse määramine radioaktiivse süsiniku meetodil Kuiksilla soos. Metsanduslikud uurimused V (Rebane, H., comp.), pp. 235-244. Valgus, Tallinn.

Ilves, E., Sarv, A. \& Valk, U. 1968. $C^{14}$ Datierungen zur Entwicklungsgeschichte der Wälder nach Materialen aus dem Hochmoor Teosaare (Estnische SSR). ENSV TA Toim. Keem. Geol., 17, 1, 53-58 (in Russian).

Iversen, J. 1973. The development of Denmark's nature since the last glacial. Danm. geol. unders., ser. V, 7-C.

Junttila, O. \& Skaret, G. 1990. Growth and survival of seedlings of various Picea species under northern climatic conditions. Scand. J. For. Res., 5, 69-81.

King, G. A. \& Herstrom, A. A. 1997. Holocene tree migration rates objectively determined from fossil pollen data. In Past and Future Rapid Environmental Changes: the Spatial and Evolutionary Responses to Terrestrial Biota (Huntley, B., Cramer, W., Morgan, A. V., Prentice, H. C. \& Allen, J. R. M., eds.). NATO ASI Series, 1, 47, 91-101.

Koff, T. 1984. On the possibilities of the formation of pollen spectra in mire and lake sediments (on the example of Viitna district, North Estonia). In Khronologiya i formirovanie chetvertichnogo pokrova Éstonii (Raukas, A., ed.), pp. 37-50. Institut geologii, Akademiya nauk ESSR, Tallinn (in Russian). 
Koff, T. 1994. The development of vegetation. In The Influence of Natural and Anthropogenic Factors on the Development of Landscapes (Punning, J.-M., ed.), pp. 24-57. Institute of Ecology, Estonian Academy of Sciences.

Königsson, L.-K. \& Poska, A. 1998. Pitkasoo - a West Estonian Holocene reference site. Proc. Estonian Acad. Sci. Geol., 47, 4, 242-261.

Königsson, L.-K., Saarse, L. \& Veski, S. 1998. Holocene history of vegetation and landscape on the Kõpu Peninsula, Hiiumaa Island, Estonia. Proc. Estonian Acad. Sci. Geol., 47, 1, 3-19.

Köstler, J. 1956. Silviculture. Oliver and Boyd, Edinburgh.

Kullman, L. 1996. Norway spruce present in the Scandes Mountains, Sweden at 8000 BP: new light on Holocene tree spread. Global Ecol. Biogeogr. Lett., 5, 94-101.

Kullman, L. 1998. Non-analogous tree flora in the Scandes Mountains, Sweden, during the early Holocene - macrofossil evidence of rapid geographic spread and response to palaeoclimate. Boreas, 27, 3, 153-161.

Lepland, A., Hang, T., Kihno, K., Sakson, M., Sandgren, P. \& Lepland, A. 1996. Sea-level changes and environmental history in the Narva area, north-eastern Estonia. PACT, 51, 313-358.

Miidel, A., Hang, T., Pirrus, R. \& Liiva, A. 1995. On the development of the southern part of Lake Peipsi in the Holocene. Proc. Estonian Acad. Sci. Geol., 44, 1, 33-44.

Moe, D. 1970. The Post-Glacial immigration of Picea abies into Fennoscandia. Bot. Notes, 123, 61-66.

Orgla, K. 1983. The experience of using trend-analysis for paleobotanical reconstruction, exemplified by the spread of the spruce in NW East European Plain. In Palynologic Researches in Geologic Studies of the Baltic Region and the Baltic Sea (Bartosh, T. D., ed.), pp. 18-23. Zinatne, Riga (in Russian).

Pirrus, R. 1969. Stratigraphic division of South Estonian Late Glacial deposits by means of pollen analyses. ENSV TA Toim. Keem. Geol., 18, 2, 181-190 (in Russian).

Pirrus, R. 1976. New information about stratigraphic subdivision of Late Glacial deposits of Kunda section (North Estonia). In Palynology in Continental and Marine Geologic Investigations (Bartosh, T. D., ed.), pp. 60-71. Zinatne, Riga (in Russian).

Pirrus, R., Rõuk, A.-M. \& Koff, T. 1987a. Geology and development of a kettlehole on the Laiuse drumlin (eastern Estonia). Proc. Estonian Acad. Sci. Geol., 36, 1, 1-5 (in Russian).

Pirrus, R., Rõuk, A.-M. \& Liiva, A. 1987b. Geology and stratigraphy of the reference site of Lake Raigastvere in Saadjärv drumlin field. In Palaeohydrology of the Temperate Zone II. Lakes (Raukas, A. \& Saarse, L., eds.), pp. 101-122. Valgus, Tallinn.

Pirrus, R., Hang, T. \& Liiva, A. 1993. On the geological development of the Väike-Emajõgi valley and the southern part of Lake Võrtsjärv. Proc. Estonian Acad. Sci. Geol., 42, 1, 28-37 (in Russian).

Poska, A. \& Saarse, L. 1999. Holocene vegetation and land-use history in the environs of Lake Kahala, northern Estonia. Veget. Hist. Archaeobot. (in press).

Punning, J.-M., Ilomets, M., Koff, T., Rajamäe, R., Petersen, I. \& Tiits, T. 1985. Stratigraphic and Palaeogeographic Investigations of Lacustrine and Bog Sediments from Vällamäe KettleHole (SE Estonia). Preprint. Academy of Sciences of the ESSR, Tallinn (in Russian).

Punning, J.-M., Koff, T., Ilomets, M. \& Jõgi, J. 1995. The relative influence of local, extra-local, and regional factors on organic sedimentation in the Vällamäe kettle hole, Estonia. Boreas, 24, 65-80.

Raukas, A., Saarse, L. \& Veski, S. 1995. A new version of the Holocene stratigraphy in Estonia. Proc. Estonian Acad. Sci. Geol., 44, 4, 201-210.

Saarse, L. 1994. Bottom Deposits of Small Estonian Lakes. Institute of Geology, Estonian Academy of Sciences, Tallinn (in Russian).

Saarse, L. \& Königsson, L.-K. 1992. Holocene environmental changes on the Island of Saaremaa, Estonia. PACT, 37, 97-131.

Saarse, L. \& Liiva, A. 1995. Geology of the Äntu group of lakes. Proc. Estonian Acad. Sci. Geol., 44, 2, 119-132. 
Saarse, L. \& Rajamäe, R. 1997. Holocene vegetation and climatic change on the Haanja Heights, SE Estonia. Proc. Estonian Acad. Sci. Geol., 46, 2, 75-92.

Saarse, L., Veski, S., Heinsalu, A., Rajamäe, R. \& Martma, T. 1995. Litho- and biostratigraphy of Lake Päidre, South Estonia. Proc. Estonian Acad. Sci. Geol., 44, 1, 45-59.

Saarse, L., Poska, A., Kaup, E. \& Heinsalu, A. 1998. Holocene environmental events in the Viitna area, North Estonia. Proc. Estonian Acad. Sci. Geol., 47, 1, 31-44.

Serebryannyi, L. R. 1971. Post-glacial migration rates of some tree species in the north-western area of the USSR. In Holocene Palynology (Neustadt, M. I., ed.), pp. 17-31. Institute of Geography, Academy of Sciences of the USSR, Moscow (in Russian).

Sarv, A. 1983. Stratigraphical subdivision of the Holocene bog and lacustrine deposits of the Remmeski and Senno sections. In Palynologic Researches in Geologic Studies of the Baltic Region and the Baltic Sea (Bartosh, T. D., ed.), pp. 77-83. Zinatne, Riga (in Russian).

Sarv, A. \& Ilves, E. 1971. Radiocarbon dating of bog-lacustrine deposits of the Vaharu bog (northwestern Estonia). In Palynological Research in the Peribaltic, pp. 143-149. Zinatne, Riga (in Russian).

Sarv, A. \& Ilves, E. 1975. Über das Alter der holozänen Ablagerungen im Mündungsgebiet des Flusses Emajõgi (Saviku). ENSV TA Toim. Keem. Geol., 24, 1, 64-69 (in Russian).

Sarv, A. \& Ilves, E. 1976. Geochronological subdivision of Holocene bog-lacustrine deposits in south-western Estonia. In Palynology in Continental and Marine Geologic Investigations (Bartosh, T. D., ed.), pp. 47-59. Zinatne, Riga (in Russian).

Tallantire, P. A. 1972. Spread of spruce (Picea abies (L.) Karst.) in Fennoscandia and possible climatic implications. Nature, 236, 64-65.

Thomson, P. 1927. Metsade arenemine Eestis postglatsiaalses ajajärgus. In Eesti metsanduse aastaraamat II, pp. 44-47. Akadeemiline Metsaselts, Tartu.

Thomson, P. 1929. Die Regionale Entwicklungsgeschichte der Wälder Estlands. Tartu Ülikooli Geoloogia-Instituudi Toimetused, 19.

Thomson, P. 1939. Ülevaade Eesti soodest. Eesti Loodus, 2/3, 90-98.

Veski, S. 1998. Vegetation history, human impact and palaeogeography of West Estonia. Pollen analytical studies of lake and bog sediments. STRIAE, 38.

Vuorela, I. 1970. The indication of farming in pollen diagrams from southern Finland. Acta Bot. Fenn., 87.

\section{LEPA JA KUUSE LEVIK EESTIS}

\section{Leili SAARSE, Anneli POSKA ja Siim VESKI}

On vaadeldud lepa (Alnus glutinosa, A. incana) ja kuuse (Picea abies (L.) Karst.) sisserännet ja levikut $43{ }^{14} \mathrm{C}$-meetodil dateeritud ja palünoloogiliselt analüüsitud läbilõike ning 10 makrojäänuste leiu põhjal. Lepp ilmus holotseensetesse õietolmuspektritesse $9200-7700$ aastat tagasi ja levis laiemalt boreaalis ning atlantikumi esimesel poolel. Levik oli küll võrdlemisi lühiajaline, kuid sporaadiline, varieerudes nii regiooniti kui ka lähedalasuvates läbilõigetes, mistõttu kindlaid sisserände suundi pole võimalik kindlaks teha. Et lepp eelistab niiskemaid kasvukohti, levis ta preboreaali lõpul enam Põhja-Eesti rannikualal. Vastupidiselt kuusele saavutas lepp levikumaksimumi kõige hiljem Kagu-Eestis. Kuuse kolonisatsioon algas boreaalis Kagu-Eestist, liikus atlantikumi jooksul loode poole ja jõudis Põhja-Eesti rannikule umbes 5000 aastat tagasi, levides 
kiirusega keskmiselt $100 \mathrm{~m}$ aastas. Kuusk saavutas maksimaalse leviku 40002800 aastat tagasi. Kuuse teine maksimum, mis kaugeltki ei kajastu kõikidel analüüsitud õietolmudiagrammidel, jääb valdavalt ajavahemikku 2000-1000 aastat tagasi. Esimesed kuuse makrofossiilsed leiud on ajaliselt 1000-2000 aastat vanemad puu õietolmu ilmumisest spektritesse. See näitab, et tegelikult kasvas kuusk meil palju varem, kui see järeldub palünoloogilisest materjalist.

\section{РАСПРОСТРАНЕНИЕ ОЛЬХИ И ЕЛИ ПО ТЕРРИТОРИИ ЭСТОНИИ}

\section{Лейли СААРСЕ, Аннели ПОСКА и Сийм ВЕСКИ}

На основании 43 палинологических диаграмм и радиоуглеродных датировок макрофоссильных остатков из десяти местонахождений изучены пути распространения ольхи и ели по территории Эстонии. Судя по спорово-пыльцевым спектрам, ольха появилась здесь 9200-7700 лет т. н. и значительно расширила ареал своего обитания в бореале и первой половине атлантического периода. Этот процесс шел быстро, но носил случайный характер как по регионам, так и по соседним разрезам, отчего восстановить направления движения ольхи не представляется возможным. В конце пребореала она занимала широкие пространства в прибрежной части Северной Эстонии, а юго-восток “обжила" гороздо позже. Ель же, напротив, начала распространяться с юго-востока и в течение 3000 лет, продвигаясь в среднем на 100 м в год, расселилась по всей Эстонии. Ее первый максимум приходится на суббореал, т. е. на 4000-2800 годы т. н., второй - на 20001000 годы т. н. При этом пыльца ели появляется в спектрах на 1000-2000 лет позже, чем ее макроостатки. Отсюда можно сделать вывод, что ель росла в Эстонии гораздо раньше, чем показывает палинологический материал. 